\title{
POACEAE
}

\section{NAME USED IN THE FSA REGION FOR THE CYMBOPOGON EXCAVATUS-CAESIUS-GIGANTEUS COMPLEX}

Cymbopogon Spreng. is notorious for being easily divided into complexes, but within the complexes the individual species are both variable and intergrading and are often based on rather ill-defined characters. Cymbopogon excavatus Stapf, C. caesius Stapf and $C$. giganteus Chiov. are the only species in the Flora of southern Africa (FSA) region belonging to a complex easily recognizable by the lowermost internode and pedicel of the raceme that are swollen and fused. An additional character often used, but not:always easy to see, is the V-shaped median groove on the lower glume of the sessile spikelet.

Cymbopogon caesius and $C$. excavatus have been separated from each other by characters such as width of the wings of the lower glume of the sessile spikelet, shape of the leaf base and the stronger tussock growth form of $C$. excavatus (Soenarko 1977; Clayton \& Renvoize 1982). C. giganteus was separated from the two species mentioned above by its broader leaves (Clayton \& Renvoize 1982). Clayton \& Renvoize (1982) placed $C$. excavatus in synonymy under $C$. caesius, keeping $C$. giganteus a separate species. Sales (2002) kept $C$. excavatus as a synonym of $C$. caesius but reduced $C$. giganteus to a subspecies of $C$. caesius. In the FSA region the name $C$. excavatus was used for both the narrow- and much broader-leaved specimens (Chippindall 1956; Gibbs Russell et al. 1990). Sales (2002) records both subsp. caesius and subsp. giganteus for Botswana. It therefore seemed appropriate to re-examine all specimens from the $F S A$ region at PRE.

Working through the collection at PRE and using all the available literature, a number of problems become apparent. Accepting $C$. excavatus as a synonym of $C$. caesius, the main characters used in the past to separate $C$. caesius and $C$. giganteus are:

Leaf blades up to 8 (rarely 10 ) $\mathrm{mm}$ wide. ligule $1-4(-5) \mathrm{mm}$ long; culms wiry or slender . ............. caesius Leaf blades over $8 \mathrm{~mm}$ wide (e.g. Clayton \& Renvoize 1982) or (9-) 10-22 $\mathrm{mm}$ wide, ligule rarely longer than $1 \mathrm{~mm}$ : culms robust . . . . . . giganteus

There is no definition of precisely what is meant by 'wiry', 'slender' and 'robust' nor any agreement on the cut-off points of the leaf width. The width of the leaf blade on herbarium specimens may not be representative of the plant, as Sales (2002) notes 'Lamina width can vary greatly in an individual and measurements should be taken of the widest leaves in a specimen'. In Sales (2002) the specimen Skarpe 287 from Botswana housed at Kew $(\mathrm{K})$ is cited as subsp. giganteus, which according to the key has 'leaves (9-)10-22 mm wide' but in the duplicate of Skarpe 287 at PRE the leaves are no wider than $7 \mathrm{~mm}$.

The ligule length of the specimens at PRE also does not correlate with the above-mentioned characters. There are, for example, specimens with leaf blades $9-10 \mathrm{~mm}$ wide, ligules 3-5 mm long and culms varying from robust through moderately robust to slender.

Distribution also does not separate the two taxa: although specimens with, say, the broadest leaves may be more common in one area than in another, both forms occur right across the $F S A$ region.

Therefore, until further studies are done in the field or better characters are found to separate $C$. caesius from $C$. giganteus, at PRE I shall treat all specimens of which the lowermost internode and pedicel of the raceme are swollen and connate, as $C$. caesius.

\section{ACKNOWLEDGEMENTS}

I wish to thank Tom Cope, Herbarium, Royal Botanic Gardens, Kew for always being willing to help and share his vast knowledge with me. Thanks to Emsie du Plessis and Gerrit Germishuizen for the editing and helping the text to flow smoothly.

\section{REFERENCES}

CHIPPINDALL. L.K.A. 1955. A guide to the identification of grasses in South Africa. In D. Meredith. The grasses and pastures of South Africa. Trustees of the Grasses and Pastures of South Africa Book Fund, Johannesburg.

CLAYTON, W.D. \& RENVOIZE, S.A. 1982. Flora of tropical East Africa Gramineae (Pan 3): 759-761.

GIBBS RUSSELL. G.E., WATSON, L., KOEKEMOER, M., SMOOK. L. BARKER, N.P., ANDERSON, H.M. \& DALLWITZ. M.J. 1990. Grasses of southern Africa. Memoirs of the Botanical Survey of South Africa No. 58

SALES, F. 2002. Flora zambesiaca 10.4: 76-80.

SOENARKO, S. 1977. The genus Cymbopogon Spengel (Gramineae). Reinwardtia 9: 225-375

* South African National Biodiversity Institute. Private Bag X 101, (0)(0)1 Pretoria.

MS. received: 2004-10-17 